\section{Influence of Competition on the Response of Bluebunch Wheatgrass}

\section{to Clipping}

\section{W. F. MUEGGLER ${ }^{2}$}

\section{Principal Plant Ecologist, Intermountain Forest and Range Experiment Station, Forest Service, U.S. Department of Agriculture, Ogden, Utah}

\section{Highlight}

Partial reduction of competition from surrounding vegetation more than doubled the total herbage and tripled the number of flower stalks produced the following year by bluebunch wheatgrass (Agropyron spicatum). Elimination of competition resulted in a sixfold increase in herbage production and a tenfold increase in number of flower stalks. The relative depressant effects of clipping were significantly reduced by concurrent reductions in com. petition. The beneficial effects of partial reduction of competition offset the adverse effects of heavy clipping, and elimination of competition more than offset the effects of extreme clipping. Number of flower stalks is a more sensitive indicator of vigor than total herbage production. Average flower stalk and foliage culm lengths are not useful indicators of vigor.

The effects of herbage removal on range plants has been studied by many investigators. Reviews by Ellison (1960) and Jameson (1963) thoroughly cover this subject. Bluebunch wheatgrass (Agropyron spicatum) has been the object of much of this study because of its importance as forage on many western ranges (e.g., McIlvanie, 1942; Stoddart, 1946; Blaisdell and Pechanec, 1949; Heady, 1950; Branson, 1956; and Wilson et al., 1966). Such studies have concerned intensity, frequency, and time of clipping. All of these influence the severity of adverse response to clipping.

We know, however, that the amount of competition from surrounding vegetation can have a pronounced effect on the outcome of clipping studies. Jameson (1963) points out that when plots rather than individual plants are clipped, it is extremely difficult to tell whether a plant's response is to the clipping of its herbage or to changes in competition from surrounding vegetation. This complication was evident in a study on the effects of time of clipping on mountain grassland species in Montana (Mueggler, 1967). On the other hand, it is unlikely that the clipping response of isolated plants lacking competition from surrounding vegetation will be equivalent to the response of plants grazed on the range. Obviously, we need to understand the rela-

\footnotetext{
1 Received April 24, 1971.

${ }^{2}$ Author stationed in Bozeman, Montana, at Forestry Sciences Laboratory, maintained in cooperation with Montana State University.
}

tive effects of clipping, of competition, and of their interaction to reliably interpret the direct effects of clipping.

The effects of competition on plant growth are known in a general way, but this factor seldom has been evaluated in clipping studies. Risser (1969), in a review of competition studies, concludes that the yield per plant invariably decreases with increasing plant density and that widely spaced plants generally produce the maximum number of seeds per individual. In other words, competition is a definite restraint on the herbage and seed yields of individual plants. From studies involving bluebunch wheatgrass, Daubenmire (1940) concluded that competition checks the stature of even the most dominant plants in a natural community.

Recently, I published the results of a study evaluating the combined effect of competition and clipping on Idaho fescue (Festuca idahoensis) that clearly demonstrates competition's suppressing action (Mueggler, 1970). I concluded that the detrimental effects of clipping Idaho fescue decline progressively as competition decreases.

This paper reports results of a similar study on bluebunch wheatgrass. It shows the influence of competition on the ability of this grass to withstand heavy and extremely heavy clipping.

\section{Methods}

The study area, a natural mountain grassland in southwestern Montana, was on a gently sloping, north-facing swale, approximately $6,000 \mathrm{ft}$ in elevation. The granitic soils were fairly deep and productive. Precipitation 2 miles north of the study area and about $1,000 \mathrm{ft}$ lower in elevation averages $15^{1 / 2}$ inches per year, of which approximately 70\% falls from April through September. Fffective precipitation on the study area was somewhat greater than this as was evidenced by the more luxuriant growth of vegetation.

The vegetation was dominated by bluebunch wheatgrass, Idaho fescue, and silvery lupine (Lupinus argenteus). Secondary species included yarrow (Achillea millefolium), cerastium (Cerastium arvense), prairiesmoke (Geum triflorum), needlegrass (Stipa columbiana), sagewort (Artemisia ludoviciana), rabbitbrush (Chrysothamnus nauseosus), and pussytoes (Antennaria rosea). Ground cover was relatively continuous and little bare soil was exposed, in contrast to conditions usually found on drier sites dominated by bluebunch wheatgrass. Moreover, plants competing with bluebunch wheatgrass were generally more numerous in quantity and variety than those usually found on drier sites. The vegetation was protected from grazing for 1 year prior to and during the study and had been grazed only moderately earlier.

One hundred and thirty-five mature, vigorous bluebunch wheatgrass plants were selected for study. Selection was based on uniformity of size and vigor and of associated vegetation. All plants were medium-sized bunches; none had the large, coarse "wolfish" characteristics sometimes found in more open stands. Selected plants were randomly assigned to nine separate treatments that yielded 15 replications per treatment. 


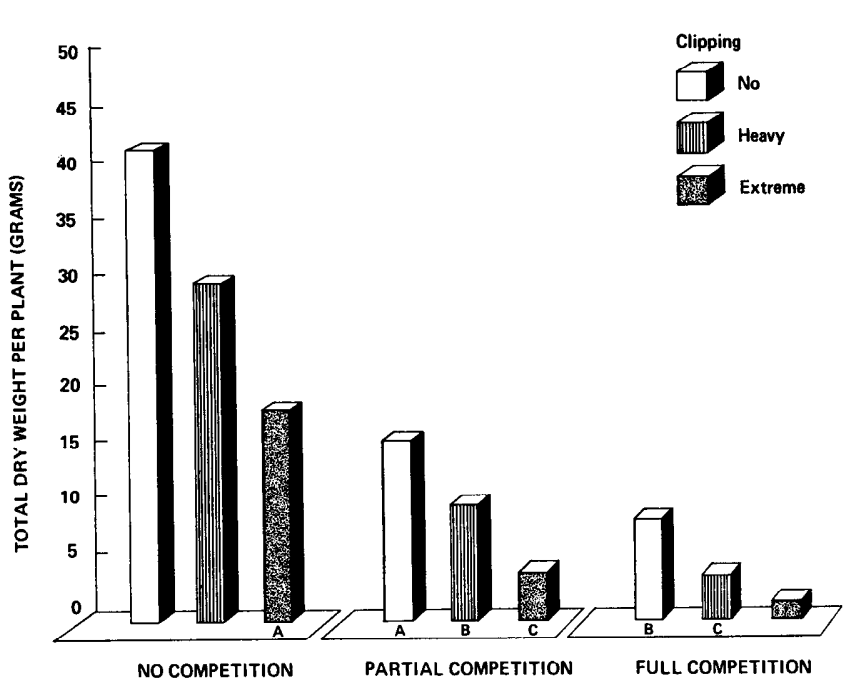

Fig. 1. Production of bluebunch wheatgrass under different levels of competition the year following clipping. (Column third from the right represents control plants-full competition, no clipping. Columns having the same letter do not differ significantly $[\mathrm{P}>.05])$.

The nine treatments consisted of all combinations of three levels of competition and three levels of clipping. The levels of competition, full, partial, and no competition, were created immediately prior to the clipping treatments. Full competition was obtained by permitting the natural vegetation to remain undisturbed around the bluebunch wheatgrass plants selected for this treatment.

The degree of partial competition was created by clipping to ground level all vegetation within a $90-\mathrm{cm}$ radius of the selected bluebunch wheatgrass plants. The clipped material was removed from the plot. This was done without disturbing the soil or directly harming the root crowns of the competing vegetation, which was permitted to regrow without further hindrance. The degree of no competition was achieved by tilling the soil 5- to $8-\mathrm{cm}$ deep within a $90-\mathrm{cm}$ radius of the selected bluebunch wheatgrass plants. The soil immediately adjacent to the plants was carefully hoed to effectively remove all competing vegetation. Tilled areas were weeded periodically during the study to maintain competition-free conditions. Conceivably, such tillage might also have affected aeration, infiltration, and nitrogen availability within the soil, which in turn could have affected subsequent growth of study plants.

The three levels of clipping bluebunch wheatgrass were no, heavy, and extreme. An unclipped control constituted the no-clipping level. The heavy level of clipping consisted of removing $50 \%$ of the herbage weight just before full emergence of the flower stalks (June 25). This growth stage is generally recognized as being within the period when bluebunch wheatgrass is most sensitive to clipping (McIlvanie, 1942; Blaisdell and Pechanec, 1949; Wilson et al., 1966). Removal of approximately $50 \%$ of the plant's weight was achieved by clipping to a stubble height equal to $28 \%$ of the plant's height (Heady, 1950). Extreme clipping was achieved by removing $50 \%$ of the herbage weight just before flower stalk emergence, followed by clipping regrowth to a uniform 8-cm stubble height when the control plants were at the seed-in-dough developmental stage

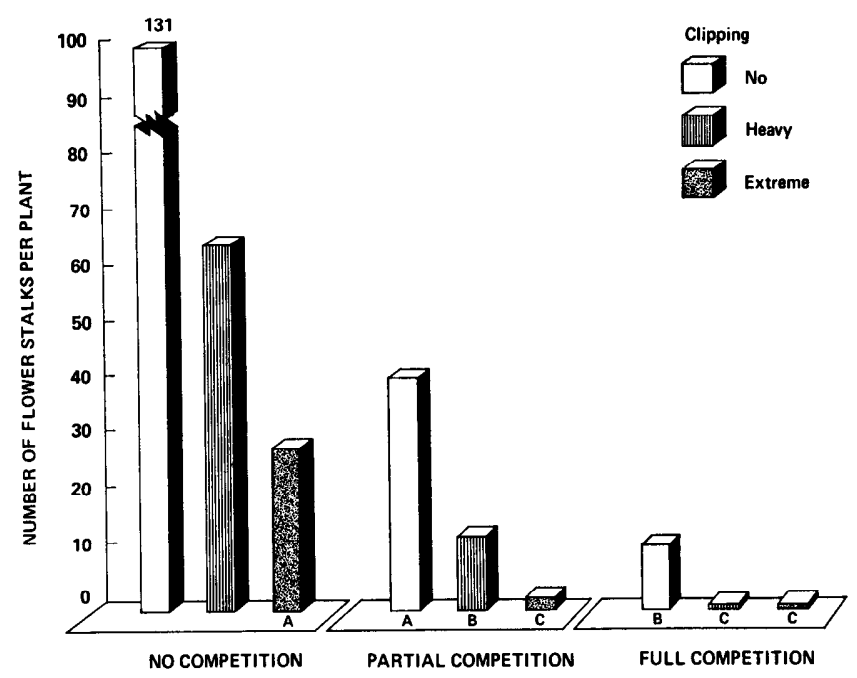

Fig. 2. Flower stalk numbers of bluebunch wheatgrass under different levels of competition the year following clipping. (Column third from the right represents control plants-full competition, no clipping. Columns having the same letter do not differ significantly $[\mathbf{P}>.05])$.

(July 17). The plants were clipped during the one growing season only.

The response of bluebunch wheatgrass was determined after flowering 1 year following treatment (clipping) by counting vegetative and flower stalk culms and by measuring maximum and average lengths of those culms. An indirect method of determining weight was necesitated to preserve the treated plants for further study. Average weights of individual culms by length classes were determined from samples collected from nearby plants not included in the study. Regression equations with $\mathrm{r}^{2}$ values exceeding .97 were developed for flowering and foliage culms to derive culm dry weights from culm lengths. These equations were used to compute the dry weight of each bluebunch wheatgrass plant from the number and the average length of culms per plant. The data were then subjected to analyses of variance. Wherever appropriate, individual treatment means were compared by the Keuls sequential range test (Snedecor, 1956).

\section{Results}

Both the competition and the clipping treatments strikingly affected plant growth the following year. Herbage production and flower stalk numbers decreased with increased levels of competition and intensities of clipping (figs. 1 and 2).

Under partial competition, unclipped bluebunch wheatgrass produced twice as much herbage and three times as many flower stalks as unclipped plants subjected to full competition. Without competition, unclipped plants produced 6 times more herbage and 10 times more flower stalks than unclipped plants growing in undisturbed vegetation. Obviously, the production of individual bluebunch wheatgrass plants is greatly suppressed by competition from surrounding vegetation. Reduction of competition alone did not significantly affect either 
Table 1. Maximum flower stalk and foliage culm lengths (cm) of bluebunch wheatgrass the year following clipping and competition treatments.

\begin{tabular}{lccl}
\hline \hline & \multicolumn{3}{c}{ Competition } \\
\cline { 2 - 4 } Treatment & No & Partial & Full \\
\hline Maximum flower stalk lengths & & \\
No clipping & $58 \mathrm{a}^{1}$ & $58 \mathrm{a}$ & $52 \mathrm{a}$ \\
Heavy clipping & $55 \mathrm{a}$ & $43 \mathrm{bc}$ & $37 \mathrm{c}$ \\
Extreme clipping & $49 \mathrm{ab}$ & $36 \mathrm{c}$ & $38 \mathrm{c}$ \\
Maximum foliage culm & length & & \\
No clipping & $33 \mathrm{e}$ & $33 \mathrm{e}$ & $35 \mathrm{de}$ \\
Heavy clipping & $38 \mathrm{~d}$ & $33 \mathrm{e}$ & $33 \mathrm{e}$ \\
Extreme clipping & $35 \mathrm{de}$ & $31 \mathrm{e}$ & $32 \mathrm{e}$ \\
\hline
\end{tabular}

${ }_{1}$ Numbers having the same letter do not differ significantly $(\mathbf{P}>.05)$.

the length of foliage culms or the length of flower stalks (Table 1).

Bluebunch wheatgrass subjected to the combined stress of heavy clipping and full competition produced $43 \%$ less herbage and $95 \%$ fewer flower stalks the following year than were produced by unclipped plants growing under full competition. Extreme clipping reduced production $72 \%$ and flower stalk numbers $97 \%$. The maximum length of flower stalks was reduced approximately $25 \%$ by both clipping treatments, but foliage culm length was not significantly affected.

Interaction between the competition and clipping treatments significantly affected herbage production and flower stalk numbers. Although this interaction was not great (less than $3 \%$ of the accountable variance), it tended to reduce the relative effects of clipping as competition declined. The relative effects of clipping on production were approximately the same under full and partial competition; heavy clipping reduced production $38 \%$ and extreme clipping reduced it $75 \%$. However, where competition was eliminated, heavy clipping reduced production only $29 \%$ and extreme clipping reduced production only $57 \%$. Effects of clipping on flower stalk numbers lessened progressively as competition was reduced. Heavy clipping of plants growing under full competition reduced the number of flower stalks $95 \%$, of those under partial competition $68 \%$, and of those without competition only $50 \%$. (Flower stalk numbers on clipped plants were compared to those of unclipped plants growing under the same levels of competition.) Extreme clipping of plants growing under full competition reduced flower stalk numbers $97 \%$, 95\% under partial competition, and $79 \%$ under no competition.

Interaction also occurred between the two treatments as they affected flower stalk lengths. Although the maximum length of flower stalks was
Table 2. Percentage of bluebunch wheatgrass plants producing flower stalks the year following clipping and competition treatments.

\begin{tabular}{lccc}
\hline & \multicolumn{3}{c}{ Competition } \\
\cline { 2 - 4 } Clipping & No & Partial & Full \\
\hline No & 100 & 100 & 80 \\
Heavy & 100 & 100 & 53 \\
Extreme & 100 & 40 & 20 \\
\hline
\end{tabular}

reduced significantly by clipping plants growing under full and partial competition, clipping did not cause a significant reduction in stalk lengths of plants without competition. This agrees well with the data on herbage production and flower stalk numbers. It reinforces the conclusion that the effects of clipping by itself are not as harmful to bluebunch wheatgrass when it is growing free from competition as when it is surrounded by competing vegetation.

Only $80 \%$ of the unclipped plants growing under full competition flowered (Table 2). Clipping greatly reduced this percentage. Heavy clipping under full competition affected plants more severely than the data suggest; most of the $53 \%$ of the plants that flowered produced only one flower stalk per plant. Few plants growing under full competition flowered after extreme clipping. All plants flowered under partial competition, except those in the extreme clipping group; only $40 \%$ of the latter managed to send up flower stalks the year following treatment. All plants clipped under competition-free conditions flowered the following year.

\section{Discussion}

These data show that natural competition severely restricts the growth and vigor of bluebunch wheatgrass. The more than doubling of herbage production the following growing season because of a partial reduction in competition is similar to but somewhat greater than that shown by Mueggler (1970) for Idaho fescue. The number of flower stalks more than tripled in both cases. Howcver, Daubenmirc (1940) found that in eastern Washington bluebunch wheatgrass released from competition by ground level clipping did not respond appreciably until the treatment was repeated for 3 successive years. The reason for this lag in response is speculatory, but it could have resulted from differences in associated vegetation, weather, or because a smaller area of surrounding vegetation was clipped.

The similarity between the production of the unaltered control and that of heavily clipped bluebunch wheatgrass under partial competition is of considerable interest. Neither their herbage pro- 
duction nor flower stalk numbers differed significantly the year following treatment. Apparently, the beneficial effects of reduced competition obtained by clipping surrounding vegetation to ground level completely offset the adverse effects of heavy clipping. Almost identical results were observed in my study of Idaho fescue (Mueggler, 1970). This suggests that both bluebunch wheat grass and Idaho fescue can rapidly recover from the adverse effects of heavy clipping if the competing vegetation is temporarily suppressed.

The significant interaction found between the effects of clipping and those of competition has considerable importance in the interpretation of clipping studies. Competition effects are usually ignored in clipping studies. Competition is held more or less constant and the effects of clipping are expressed in relative terms; the investigator assumes that the "relative" effects will be the same regardless of competition level. The vulnerability of such an assumption is demonstrated by this study on bluebunch wheatgrass and the one on Idaho fescue (Mueggler, 1970). Heavy clipping under competition-free conditions suppressed production of bluebunch wheatgrass only two-thirds as much as heavy clipping under full competition. Heavy clipping suppressed flower stalk production only one-half as much on plants growing under no competition as on plants growing under full competition. Suppression of both herbage and flower stalk production by extreme clipping of plants under competition-free condition was about $4 / 5$ that of plants subjected to extreme clipping and full competition. Production of Idaho fescue was suppressed only $1 / 2$ as much by heavy and extreme clipping under no competition as by similar clipping under full competition. When Idaho fescue without competition was subjected to heavy and extreme clipping flower stalk reductions were only $1 / 5$ and $3 / 4$ that caused by heavy and extreme clipping under conditions of full competition.

Neither competition-free nor full competition conditions represent the competition levels existing under moderate grazing. The true level no doubt varies, but probably falls somewhere between the full and partial competition levels achieved in this study. Relative production declines caused by clipping bluebunch wheatgrass growing under partial competition were within $10 \%$ of those growing under full competition. However, relative declines in production of Idaho fescue growing under partial competion varied with clipping intensity: the production decline following heavy clipping was similar under both partial and no competition; the decline following extreme clipping was halfway between that of plants growing under no and full competition. Comparative reductions in flower stalk numbers obtained by heavy clipping of both species growing under partial competition were about halfway between those of plants growing under full and no competition; reductions resulting from extreme clipping were practically identical to those observed in plants growing under full competition. Clipping studies conducted on plants growing under full competition probably will yield results closer to those from actual moderate grazing than will clipping studies under competition-free conditions.

Flower stalk numbers were affected more by the competition and clipping treatments than total herbage production. Maximum lengths of flower stalks and leaf culms were affected least. Average lengths were not changed appreciably. Consequently, flower stalk numbers appear to be the best indicator of vigor in bluebunch wheatgrass. These findings agree with those of Blaisdell and Pechanec (1949) and Heady (1950) for bluebunch wheatgrass and with those of Mueggler (1967, 1970) for Idaho fescue.

The results of this study on bluebunch wheatgrass, and its companion study on Idaho fescue (Mueggler, 1970) emphasize the nced for caution when results of clipping studies are applied to plants grazed on the range. In addition, the relation of these results to rest-rotation grazing is of special interest. As Hormay and Talbot (1961) originally described rest-rotation grazing, a fairly heavy stocking rate is desirable to force use of the less palatable species. My studies on clipping Idaho fescue and bluebunch wheatgrass support this feature of rest-rotation grazing and suggest that forced use of the less palatable species reduces the ability of these plants to compete with more palatable species. Reduced competition, combined with rest, permits the more palatable species to recover rapidly from the adverse effects of heavy utilization. However, in modifying the original rest-rotation concept to include more and more plant communities and situations, Hormay (1970) has apparently discarded the idea of forced use as he suggests that no attempt be made to graze the vegetation to any particular degree.

A problem may have been created by the extension of rest-rotation grazing to all types of range. Logic indicates that this grazing system has a grcater chancc of succceding on grasslands where most of the vegetation is fairly palatable than on areas where unpalatable species such as sagebrush (Artemisia spp.) and wyethia (Wyethia spp.) are prominent components of the stand. In any event, it seems necessary to balance desirable effects of heavy grazing in a rest-rotation system against undesirable effects on livestock weights, watershed protection, and esthetics. Modification of the original system to avoid heavy utilization actually 
may result in slower range improvement than might otherwise be possible-an unusual dilcmma for the range manager!

\section{Literature Cited}

Blaisdell. J. P., and J. F. Pechanec. 1949. Effects of herbage removal at various dates on vigor of bluebunch wheatgrass and arrowleaf balsamroot. Ecology 30:298-305.

Branson, F. A. 1956. Quantitative effects of clipping treatments on five range grasses. J. Range Manage. 9: 86-88.

Daubenmire, R. F. 1940. Plant succession due to overgrazing in the Agropyron bunchgrass prairie of southeastern Washington. Ecology 21:55-64.

ELLISON, L. 1960. Influence of grazing on plant succession of rangelands. Bot. Rev. 26:1-78.

HEADY, H. F. 1950. Studies on bluebunch wheatgrass in Montana and height-weight relationships of certain range grasses. Ecol. Monogr. 20:55-81.

HoRmay, A. L. 1970. Principles of rest-rotation grazing and multiple-use land management. USDA Forest Service Training Text 4, $26 \mathrm{p}$.

Hormay, A. L., and M. W. Talbot. 1961. Rest-rotation grazing ... a new management system for perennial bunchgrass ranges. USDA Forest Service, Prod. Res. Rep. $51,43 \mathrm{p}$.

Jameson, D. A. 1963. Response of individual plants to harvesting. Bot. Rev. 29:532-594.

MCILVANIE, S. K. 1942. Carbohydrate and nitrogen trends in bluebunch wheatgrass, Agropyron spicatum, with special reference to grazing influences. Plant Physiol. 17:540-557.

MUEGGLER, W. F. 1967. Response of mountain grassland vegetation to clipping in southwestern Montana. Ecology 48:942-949.

MUEGGLER, W. F. 1970. Influence of competition on the response of Idaho fescue to clipping. USDA Forest Serv. Res. Paper INT-73, $10 \mathrm{p}$.

Risser, P. G. 1969. Competitive relationships among herbaceous grassland plants. Bot. Rev. 35:251-284.

SNedeCOR, G. W. 1956. Statistical Methods. 534 p. Ames, Iowa: Iowa State Coll. Press.

Stoddart, L. A. 1946. Some physical and chemical responses of Agropyron spicatum to herbage removal at various seasons. Utah State Agr. Exp. Sta. Bull. 324, $24 \mathrm{p}$.

Wilson, A. M., G. A. Harris, and D. H. Gates. 1966. Cumulative effects of clipping on yield of bluebunch wheatgrass. J. Range Manage. 19:90-91. 